\title{
Genpolitisering og postdemokratisering Studiet af mellemøstlig politik i lyset af de arabiske revolter
}

Morten Valbjørn ph.d. og lektor ved Institut for Statskundskab, Aarhus Universitet.

E-mail: mortenv@ps.au.dk

Rasmus Alenius Boserup ph.d. og postdoc ved Dansk Institut for Internationale Studier.

E-mail: rab@diis.dk

Frem for enten at tale om, at den arabiske verden nu befinder sig i en transition to democracy eller fortsat er kendetegnet ved en 'transition to nowhere', synes det mere præcist at beskrive den aktuelle udvikling som en transition to somewhere markeret ved en bred genpolitisering af de arabiske samfund. I forståelsen heraf er postdemokratiseringsperspektivet fortsat nyttigt, men bør opgraderes.

I 2002 noterede nu afdøde Fred Halliday (2002, 235), at „der findes to forudsigelige og næsten altid forkerte reaktioner på enhver stor international begivenhed: Den ene hævder, at alt er forandret; den anden hævder, at intet er forandret."

Halliday refererede til reaktionerne på 9/11, der som empirisk fænomen udfordrede en række centrale antagelser i islamismeforskningen og i den bredere forskning i arabisk politik. Ti år senere står den del af mellemøstforskningen, der beskæftiger sig med regionens politiske orden, i et lignende dilemma: De arabiske revolter i 2011 har afsløret sider af det empiriske felt, der udfordrer centrale antagelser i forskningen. Som Halliday forudså, har de skelsættende begivenheder også denne gang drevet nogle iagttagere til at hævde, at alt nu er helt forandret, mens andre fastholder, at intet grundlæggende er ændret: Mens visse stemmer genoplivede 1990'ernes transitologiske demokrati-optimisme, forudsagde andre således, at de seneste årtiers autoritære orden ville fortsætte.

Frem for at vælge lejr i denne debat vil vi i det følgende skitsere en form for tredje vej. I Hallidays ånd søger vi både at anerkende og kombinere indsigter fra begge lejre på basis af, hvad vi - med en parafrasering til Steven Heydemann (2007) - betegner som en opgraderet postdemokratiseringstilgang. Denne fastholder visse grundlæggende antagelser fra postdemokratiseringsperspektivet, samtidig med at der både tages højde for den berettigede kritik af dette og for de vigtige forandringer, som vi mener, der er sket i den arabiske verden i 2011.

I artiklens første del introduceres postdemokratiseringstilgangen samt baggrunden for, hvordan denne opstod som en kritik af den demokrati-optimisme, som var udbredt i en del af 1990'ernes mellemøstforskning. Mens beskrivelsen af den arabiske verden som værende i en transition to nowhere frem for en transition to democracy har været ganske rammende for den politiske udvikling gennem de seneste årtier, har dette forandret sig med de arabiske revolter, som har bragt regionen ind $\mathrm{i}$, hvad vi betegner som en transition to somewhere (Valbjørn 2012). I artiklens anden del undersøger vi, hvad dette somewhere nærmere bestemt er karakteriseret ved, og foreslår, at det egentlige nye er, hvad vi betegner som 'den arabiske politiks genkomst' (Boserup 2011). På baggrund af en kortlægning af dimensioner af både forandring og kontinuitet giver vi endelig i det tredje og sidste afsnit et bud på nogle af de elementer, som et opgraderet postdemokratiseringsperspektiv bør rumme for bedre at kunne tage højde for denne genpolitisering.

\section{Fra transition to democracy til transition to nowhere: postdemokratiseringsperspektivet}

Postdemokratiseringsperspektivet betegner en strømning inden for den politologiske del af mellemøststudierne, 
der opstod i 2000'erne som reaktion på den demokratioptimisme, der kendetegnede samme felt i 1990'erne. ${ }^{1}$ Mellemøststudiernes demokrati-optimisme i 1990'erne kan ses som del af en mere generel demokrati-optimistisk strømning i politologien. Den hentede inspiration fra den tredje demokratiseringsbølge og transitologiens anskuelse af politisk udvikling som en overgang fra autokrati til demokrati. I denne forskningstradition lå fokus ofte på, hvor langt et givet samfund var kommet i den demokratiseringsproces, som - det var forventningen - før eller siden ville gøre hele verden 'posthistorisk' i en Fukuyama'sk forstand.

Inden for mellemøstforskningen kom transitologien til udtryk i en form for studier - den såkaldte democracyspotting - der håbefuldt forsøgte at identificere små og store tegn på, at også de mellemøstlige samfund bevægede sig i retning af en demokratisering, der skulle afslutte regionens autoritære særkende og bringe Mellemøsten til, hvad Francis Fukuyama $(1989,4)$ havde beskrevet som menneskehedens ideologiske endemål: det liberale demokrati. Gennem 1990'erne blev der således optimistisk rapporteret om, hvordan en række mellemøstlige regenter ikke blot var begyndt at tale om behovet for demokratisering. De havde også iværksat en række politiske reformer, som havde udmøntet sig i gennemførelsen af valg, (gen)oprettelsen af parlamenter, introduktionen af flerpartisystemer og etableringen af et vibrerende civilsamfund. Man noterede sig samtidigt, hvordan den offentlige debat nu var præget af referencer til ta'addudiya (pluralisme) og dimuqratiyya (demokrati). På den baggrund formuleredes et forskningsperspektiv, der hævdede, at 1990'erne ville blive 'demokratiets årti', og at den langsigtede trend gik mod større liberaliseringer og mere repræsentative regeringer i den arabiske verden (Hudson 1991, 426; Norton 1993, 206).

Ved indgangen til det nye årtusinde stod det imidlertid klart, at Mellemøsten ikke befandt sig i en transition to democracy. Ikke blot figurerede den arabiske verden fortsat som klodens mindst frie region. Demokratikløften var gennem 1990'erne ligefrem blevet endnu dybere. De mange nominelle reforminitiativer syntes således blot at have bragt regionen ind i, hvad Daniel Brumberg (2003) ironisk betegnede som en transition to nowhere. På den baggrund rejste der sig omkring årtusindeskiftet en voksende kritik af de velmenende, men relativt enøjede transitologisk-inspirerede studier af mellemøstlig politik. Udover at fremhæve misforholdet mellem den forventede og den faktiske udvikling pegede kritikerne også på, hvordan det pseudo-universalistiske og kvasi-teleologiske autokrati-/demokrati-transitionsskema risikerede at skabe flere slags blindheder: dels en blindhed for, hvordan politiske reformer og valg ikke nødvendigvis er udtryk for demokratisering, idet de også kan være del af en regimebevarende strategi, der blot efterlever Lampedusas doktrin om at 'forandre for at bevare'; dels en blindhed for, hvordan den udeblevne demokratisering ikke behøver at være ensbetydende med stilstand, idet fravær af forandring af regimer ikke nødvendigvis udelukker muligheden for forandring $i$ regimer og $i$ det øvrige politiske liv.

Det var på baggrund af denne kritik, at Steven Heydemann (2002; jf. Albrecht \& Schlumberger 2004) opfordrede til, at studiet af arabisk politik trådte ind $\mathrm{i}$ 'postdemokratiseringens æra' og herved lagde navn til en af det seneste årtis toneangivende strømninger i studiet af regionens politiske orden. Den overordnede ambition i dette forskningsperspektiv var at flytte fokus fra den normative fokusering på noget ønskeligt, men fraværende (en demokratisk transition), til en mere nøgtern opmærksomhed på det faktisk nærværende, altså hvad der faktisk foregik i regionen, herunder ikke mindst hvordan de forskelligartede former for arabiske autokratier virkede, og hvilke implikationer dette havde for det øvrige politiske liv.

Denne ambition har gennem 2000'erne hovedsagligt manifesteret sig i to hovedvarianter i studiet af politisk orden i Mellemøsten. Den forste variant af postdemokratiseringstilgangen har koncentreret sig om de autoritære regimestrukturer, hvilket har afspejlet sig i, hvad André Bank (2009) har beskrevet som autoritarismestudiernes renæssance. Holger Albrecht \& Oliver Schlumberger (2004) har meget sigende foreslået, at man burde omformulere det klassiske spørgsmål om, hvordan vi skal forstå the failure of democracy - dvs. noget fraværende - til i stedet at handle om at forklare the success of authoritarianism, noget nærværende. Denne interesse for at forstå de arabiske autokratiers sejlivede og dynamiske karakter har gennem det seneste årti afspejlet sig i en voksende opmærksomhed på ligheder og forskelle mellem forskellige former for autoritære regimer, herunder monarkistiske, (post)populistiske og liberaliserende autokratier; på hvordan en 'lampedusiansk' 'forandre for at bevare'-strategi mere specifikt udmønter sig i forbindelse med valg, parlamenter, civilsamfund; på hvordan vestlige demokratifremmende initiativer ikke nødvendigvis har samme effekt i stabile liberaliserende autokratier som i samfund i reel forandring og endeligt på, hvordan globaliseringen har bidraget til at skabe, hvad Heydemann (2007) har betegnet som nye 'opgraderede' former for arabiske autokratier. Fokus har i denne variant af postdemokratiseringsperspektivet især været rettet mod regimeniveauet. I det omfang det øvrige politiske liv har været genstand for opmærksomhed, har interessen især samlet sig om, hvordan processen har givet sig til udtryk i en generel afpolitisering af befolkningerne og udbredt politisk apati. 
Den anden og mindre fremtrædende variant af postdemokratiseringsperspektivet har forsøgt at diversificere det entydige fokus på regimerne. Denne variant er ikke blot kritisk over for 1990'ernes normative og håbefulde fokusering på tegn på en forestående demokratisk revolution. Den rummer endvidere en implicit kritik af autoritarismestudiernes snævre regimefokus. Ifølge Lisa Anderson (2006) er der blot tale om transitology in reverse, idet disse studier nok flytter fokus hen på den autokratiske orden, men i bund og grund forbliver de efter Andersons mening fastlåst $\mathrm{i}$ autokrati-/demokratidikotomien. Fortalere for denne udvidede variant af postdemokratiseringsperspektivet hævder således, at der er behov for at rette fokus mod, hvad der foregår 'over', 'under' og 'hinsides' regimerne. I praksis indebærer dette en radikal udvidelse af forståelsen af, hvad der tæller som 'politik', hvem der er politisk relevante aktører, og hvor politikken finder sted. Selv om denne variant har været mindre indflydelsesrig, har denne ambition om at distancere sig fra, hvad der er blevet betegnet som en 'demokratiserings- og autoritarisme paradogma' (Valbjørn \& Bank 2010), udmøntet sig i en interesse for forandringer i det politiske liv, som ikke er direkte knyttet til regimeniveauet. Fokus har her eksempelvis været rettet mod samspillet mellem regional og lokal politik, således som det var tilfældet i et studie af, hvordan Irakkrigen påvirkede den lokale orden i områder uden for de egentlige magtcentre i hovedstæderne. Andre har diskuteret, hvordan globaliseringen har været med til at skabe nye patronagemønstre og former for aktører. Andre igen har beskæftiget sig med, hvorvidt arabiske borgere i stedet for at forsøge at skabe forandring af/i regimerne er begyndt at opbygge sociale strukturer, der eksisterede parallelt med den officielle orden. Dette spørgsmål har været knyttet til debatten om de nye transarabiske mediers rolle for (gen)skabelsen af en 'ny arabisk offentlighed', og om hvorvidt arabisk politik fortsat har en distinkt arabisk dimension.

\section{De arabiske revolter 2011: Fra transition to nowhere til transition to somewhere}

Indtil slutningen af 2010 fremstod postdemokratiseringstilgangen i sin snævre og i sin udvidede forstand som et både nyttigt og frugtbart perspektiv i studiet af Mellemøstens politiske orden. Autoritarismevarianten kunne eksempelvis forklare, hvorfor to årtiers nominel reformproces ikke havde skabt megen reel demokratisering, men eksempelvis efterladt Jordan mindre frit end ved processens begyndelse i 1989 (Valbjørn 2010), og hvordan Ægyptens liberaliseringspolitikker gennem 1980'erne og 1990 'erne ikke resulterede i større politisk demokratisering (Kienle 2001). Samtidigt havde den udvidede variant af postdemokratiseringsstudierne blik for, hvordan der trods fravær af forandringer $a f-$ og delvist også $i$ - mange af de arabiske regimer stadig foregik forandringer uden for den formelle politiske sfære.

De store omvæltninger, som dele af den arabiske verden har oplevet siden december 2010, rejser imidlertid spørgsmålet om postdemokratiseringsperspektivets fortsatte relevans for studiet af arabisk politik. Billedet af en afpolitiseret og stivnet arabisk verden med sejlivede, men dynamiske arabiske autokratier udfordres således af, hvordan 2011 ikke blot bød på en hidtil uset folkelig mobilisering med krav om demokrati og frihed, men også på flere arabiske autokraters fald begyndende med Ben Alis flugt den 14. januar 2011. Som indikeret i indledningen har der gennem 2011 været fremsat en række ganske forskellige svar på dette spørgsmål om betydningen af de arabiske revolter for postdemokratiseringsperspektivet.

På den ene side har der været en fløj, der - i tråd med Hallidays forudsigelse - er fremkommet med demokrati-optimistiske forudsigelser om fremkomsten af et helt 'nyt Mellemøsten'. Især i de første måneder var det populært at sammenligne begivenhederne med 'Murens Fald', som jo markerede begyndelsen på en demokratisk transition i Østeuropa. Der blev eksempelvist talt om et 'arabisk 1989', og om hvordan dette var begyndelsen på en 'fjerde demokratiseringsbølge' (Gershman 2011), der i modsætningen til den tredje bølge ikke ville efterlade Mellemøsten uforandret. De arabiske revolter ville således forvandle det gamle autokratiske Mellemøsten til et helt 'nyt og demokratisk Mellemøsten'. I forlængelse af disse erklæringer lød der også kritik af postdemokratiseringstilgangen og dennes pessimistiske forudsigelser om de arabiske autokratiers sejlivede karakter og den udbredte afpolitisering. I en kritik af Oliver Schlumberger - der udover at have redigeret et hovedværk om de arabiske autokratiers dynamiske og resistente karakter (Schlumberger 2007) havde sammenlignet 1990'ernes demokrati-optimisme med at 'vente på Godot' (Albrecht \& Schlumberger 2004) - anførte Adrian Lobe, eksempelvis, at de arabiske revolter ikke blot havde bragt arabiske autokrater til fald, men også de 'Gedankenhäuser' (dvs. postdemokratiseringsstrømningen), som havde spået deres forbliven (Lobe 2011; for et svar på kritikken Schlumberger 2011). Michael Hudson (2011), der i 1990'erne havde argumenteret for en forestående demokratisering, rejste endvidere spørgsmålet om, hvorvidt han og hans fæller, vitterligt også havde været så normativt forblændede, som de var blevet fremstillet, eller om det snarere var dem, der nu var blevet bekræftet. Begivenhederne gav også anledning til en vis selvransagelse hos forskere associeret med postdemokratiseringsperspektivet. Marc Lynch (2011) erklærede således, at de arabiske revolter havde undermineret litteraturen om autoritær vedholden- 
hed, og Greg Gause (2011) udpegede en række områder, som han og andre bidragydere til, hvad han nu betegnede som 'myten om autoritær stabilitet', havde fejlfortolket eller overset.

På den anden side tog en række forskere til genmæle over for kritikken af postdemokratiseringsperspektivet. Samtidig med at de understregede det ønskværdige i, at de arabiske revolter ville skabe et helt nyt og demokratisk Mellemøsten, så de imidlertid ikke tegn på noget sådant, hvorfor der heller ikke var nogen grund til at henfalde til 1990'ernes demokrati-optimisme. I en diskussion af, hvorfor de arabiske revolter hen over sommeren 2011 havde tabt luften en række steder, pegede Reinoud Leenders sammen med Heydemann (2011) eksempelvis på, hvordan diffusion og social læring ikke blot foregår blandt den meget omtalte arabiske 'Facebook-ungdom'. Som udtryk for en recombinant authoritarianism har regionens autokratier ligeledes udvist stor tilpasningsdygtighed og evne til at lære af hinandens fejl og succeser om, hvornår det er effektivt at bruge vold, og hvornår det er nyttigt at ty til varianter af den klassiske 'forandre for at bevare'-strategi. Endvidere er der blevet peget på, hvordan der selv bag dramatiske begivenheder som en regents fald kan gemme sig en mere fundamental kontinuitet. Med henvisning til det ægyptiske militærs fortsatte centrale politiske rolle har Jason Brownlee \& Joshua Stacher (2011) eksempelvis beskrevet situationen i post-Mubarak Ægypten som change of leader, continuity of system, ligesom Elis Goldberg (2011) har talt om Mubarakism without Mubarak. Endelig har Eva Bellin (2011) påpeget, at et autokratisk sammenbrud ikke behøver at være indledningen på en demokratisering. Historisk har det almindelige scenario derimod været, at ét autoritært regime afløses af et andet, som måske kan tage forskellige hybride former. Baseret på Samuel Huntingtons over 40 år gamle værk om Political Order in Changing Societies (1968) har Fukuyama (2011) på tilsvarende vis nedtonet sin tidligere optimisme og peger nu i stedet på betydningen af, men ikke mindst også vanskelighederne ved institutionsbygning, samt hvordan folkelig massemobilisering i samfund uden veludviklede politiske institutioner risikerer at udmønte sig i kaos eller nye former for autoritære regimer.

Der er således gode grunde til at være forbeholden over for skråsikre erklæringer om, at Mellemøsten nu befinder sig en transition to democracy. Samtidig er der imidlertid også grund til at være forbeholden over for idéen om, at revolterne i 2011 blot repræsenterer en fortsættelse af de seneste årtiers transition to nowhere $\mathrm{i}$ et uforandret 'gammelt Mellemøsten', og at kritikken af postdemokratiseringsperspektivet derfor blankt kan affejes. De arabiske revolter i 2011 markerer, efter vores mening, et markant historisk brud i Mellemøstens politiske og sociale historie. Det vil efterlade regionen forandret, men det er endnu for tidligt at sige, om et sådant 'nyt Mellemøsten' vil blive mere demokratisk eller ej. Frem for at se Mellemøsten som værende enten i en transition to democracy eller at befinde sig i en transition to nowhere må vi, efter vores mening, indtil videre slå os til tåls med, at regionen befinder sig i en transition to somewhere - et somewhere, der kendetegnes ved, hvad vi betegner som en bred genpolitisering af de arabiske samfund.

\section{Den arabiske politiks genkomst}

I vores læsning fremstår 2011 således som et historisk brud med den arabiske verdens nyere politiske historie ved, at der er tale om en bred og gennemgribende 'genkomst af den arabiske politik' (Boserup 2011; Boserup \& Tassinari forthcoming). I denne proces har et stort antal kollektive aktører, nydannede såvel som allerede eksisterende, demokratiske og autoritære såvel som de, der ikke kan passes ind i disse kategorier, engageret sig politisk. I lande som Ægypten og Tunesien har millioner af mennesker for første gang deltaget i gadeprotester, tusinder af nye foreninger, og netværk er blevet dannet, og hundreder af politiske partier har set dagens lys.

Den brede politisering og den politiske udvikling, der er fulgt med dette, har i første omgang bekræftet postdemokratiseringsperspektivets grundantagelse om, at forskningen bør fokusere på de arabiske regimer i et forsøg på at forstå regionens politiske orden og udviklingspotentialer. Et tilbageblik på 2011 viser, at de arabiske regimer har reageret på genpolitiseringen på, i hvert fald, fire forskellige måder.

Den forste type regimereaktion består i langstrakt eller massiv politi- og militærundertrykkelse. Mens en række regimer sporadisk har benyttet repression som ét blandt flere greb, har repression i visse lande været det dominerende aspekt af regimernes respons. Dette gælder navnlig i Libyen frem til Gaddafis fald, i Bahrain (se fx HRW 2011), i Yemen frem til Salehs afgang og forekommer stadig ved udgangen af 2011 som den dominerende policy response i Bashar al-Asads Syrien (se fx UNHRC 2011).

Den anden type regimereaktion består i proaktivt igangsatte reformprogrammer. Mens en række regimer gennem 2011 forsøgte at kombinere reformprogrammer med fx repression eller andre politikker, har den dominerende tendens i monarkierne, Marokko og Jordan, været at introducere regimeorkestrerede pre-emptive politiske reformprogrammer (Ottaway \& Muasher 2011). I Marokko er der i løbet af 2011 gennemført en grundlovsrevision, afholdt folkeafstemning om denne, og på baggrund heraf gennemført parlamentsvalg. Ligeledes er der i Jordan givet indrømmelser til demonstranterne. Al- 
lerede i februar valgte kongen at følge de folkelige krav og fyrede premierminister Rifai samtidig med, at han nedsatte en national dialogkomité og en forfatningskommission, der blandt andet skulle ændre den forkætrede valglov (Valbjørn 2011a). En anden variant af dette regimerespons har været de olieeksporterede rentierregimer, der som Saudi-Arabien har opjusteret de finansielle velfærdsydelser, som borgerne modtager, i et forsøg på at imødekomme protester.

Den tredje type regimereaktion har været elitefraktionering. I 2011 har dette reelt kun udspillet sig i to lande, Tunesien og Ægypten. Regimerne i disse lande var de første i rækken af regimer, der blev ramt af masseprotester. Det er fortløbende de to lande, hvor politiseringen også har været mest gennemgribende. Begge regimer forsøgte indledningsvis at slå demonstrationerne ned ved hjælp af det civile sikkerhedsapparat. Da dette ikke lykkedes, forsøgte begge regimer at imødekomme protesterne med løfter om vidtgående politiske reformer. Da dette heller ikke kunne tage luften ud af protesterne, vendte begge præsidenter sig imod hærledelsen, der i begge tilfælde afviste at understøtte den politiske ledelse med militærmagt. Derved blev netop regimefraktionering den afgørende faktor i de to regimers fald. I de to andre arabiske lande, hvor statsoverhoveder er faldet i 2011, har dette i mindre grad været grundet intern regimefraktionering og i højere grad grundet ekstern militær og diplomatisk involvering - NATO i Libyen og Gulf Cooperation Council (GCC) i Yemen.

Den fierde og sidste type regimereaktion har bestået $\mathrm{i}$ passiv afventen. Dette har kun været en reel mulighed de steder, hvor den folkelige mobilisering og politisering har været begrænset eller er helt udeblevet. I denne kategori finder vi regimer som Algeriet, Libanon, Irak, Sudan og Palæstina. De fleste af disse samfund rummer en række af de samme konfliktpotentialer som de steder, hvor der er udbrudt protester: høj korruption, lav politisk legitimitet, massiv ungdomsarbejdsløshed, økonomisk skævvridning, illegitime regimer, folkelig afkobling fra statsinstitutioner og politiske institutioner i særdeleshed etc. Imidlertid sidestilles de af for nyligt at have gennemgået omkostningsrige politiske kriser og væbnede konflikter. Algeriet er socialt og politisk fragmenteret og endnu på vej ud af en periode med langstrakt borgerkrig. Irak er i en politisk og social genopbygningsproces efter borgerkrigen, der fulgte den amerikansk-ledede invasion. Palæstina og Libanon har i årtier været involveret i krigsførelse med Israel såvel som interne væbnede konflikter. Sudan har efter årtiers borgerkrig mellem Nord og Syd samt etnisk udrensning i Darfur i efteråret 2010 gennemgået en af historiens få fredelige statsdelinger.
Flertydigheden i regimernes responser suppleres af en flertydighed i retninger og resultater af de følgende politiske processer. På den ene side har vi gennem 2011 bevidnet enkelte demokratiske landevindinger, som $\mathrm{fx}_{\mathrm{i}}$ Tunesien, hvor en civilt drevet overgangsproces har banet vej for etableringen af en demokratisk valgt grundlovsgivende forsamling under ledelse af en islamistisk koalitionsregering (Tassinari \& Boserup 2011). På den anden side har vi oplevet en fortsat autoritarisme i en række varianter fx i Syrien, Algeriet og Golflandene. En tredje gruppe udgøres af de lande, der ved udgangen af 2011 fremviser både demokratiske og autoritære tendenser. Et eksempel er Ægypten, hvor der i november indledtes parlamentsvalg med historisk høj valgdeltagelse og historisk lav valgsvindel - i udgangspunktet demokratiske indikatorer. Sideløbende har det ægyptiske militær gennem de sidste ti måneder massivt forøget brugen af militærdomstole (Amnesty International 2011) og ved flere lejligheder udvist autoritære tendenser i forsøget på at bibeholde institutionens privilegier inden for politik og økonomi (Ottaway 2011). I monarkierne Marokko og Jordan er den politiske reformproces fra en række sider blevet kritiseret for at være et 'lampedusiansk' projekt, hvor de liberaliserende autokratier 'forandrer for at bevare' de faktiske magtforhold. Situationen efter det marokkanske valg i november 2011 er eksempelvis blevet beskrevet som new actors same script (Errazzouki 2011), og i Jordan fremviser processen en række fællestræk med 1989: I begge perioder har svære socioøkonomiske problemer udløst protester med krav om demokratiske reformer. Kongen har reageret ved først at fyre premierminister Rifai (dengang Zaid og i 2011 dennes søn Samir) og herpå indlede en 'national dialog' resulterende i en ny 'pagt' mellem kongen og folket (dengang det såkaldte 'Nationale Charter' og i 2011 i form af forfatningsændringer). Men ligesom dengang er der (endnu) ingen klare tegn på, at der er tale om mere end facadedemokratisering (Valbjørn 2011a).

Disse flertydigheder i den politiske udvikling gør det efter vores mening endnu for tidligt at afgøre, hvorvidt der er tale om demokratisering eller autoritær konsolidering. Hvad vi omvendt kan konkludere, er, at 2011 med al tydelighed viser, at regimernes respons på politiseringen har afgørende betydning for den politiske udvikling i de enkelte stater. Det er således i de lande, hvor politiseringen har medført regimefraktionering og kollaps, Tunesien og Ægypten, at der gennem 2011 er opstået de største potentialer for demokratisering - om end det endnu er uklart, om der i sidste ende bliver tale om en reel demokratisering. Omvendt er det i de lande, hvor politiseringen ikke medførte regimefraktionering, at der er forekommet tydelige tendenser til autoritær konsolide- 
ring via repression og via top-down-reforminitiativer - om end disse processer heller ikke er afsluttede.

Mens udviklingen i 2011 således har bekræftet relevansen af et fortsat fokus på de arabiske regimer og deres regimebevarende strategier, har den også udstillet en tendens især hos visse dele af postdemokratiseringsperspektivet til at være blind for former for politik, der ikke er direkte knyttet til regimeniveauet. Der kan givetvis peges på en række områder i gråzonen mellem politisk og anden form for kollektiv aktivisme, som dette perspektiv fortløbende overser - $\mathrm{fx}$ de subtile omstruktureringer af ledelseshierarkier og ledelseskulturer internt i statsinstitutioner, universiteter, læreanstalter, og medieorganisationer i fx Ægypten i dag (Brown 2011). Vi skal her begrænse os til at diskutere tre områder, hvis politiske betydning var blevet helt eller delvis nedprioriteret i de sidste ti års postdemokratiseringsperspektiv.

Den forste type politik er forekommet 'uden for' regimernes rutineprægede, bureaukratiserede og institutionaliserede politiske sfære. Den består i en eksplosiv stigning i folkelig deltagelse i såkaldt contentious politics. I løbet af året har der udspillet sig et uhørt stort antal demonstrationer, protestmarcher, kontraprotestmarcher, sit-ins, kampagner, strejker og anden form for ikke-institutionaliseret gadepolitik. Størstedelen af disse begivenheder - fra de tunesiske demonstrationer i foråret til de pågående i Syrien - organiseres som fredelige aktioner i den forstand, at vold og hærværk ikke i udgangspunktet er en del af taktikken. I Tunesien og Ægypten var det denne type contentious politics, der grundet sin massive karakter skabte splid internt i den politiske elite. I begge lande har denne type politik gennem 2011 fortsat spillet en afgørende rolle for den retning, som den videre politiske udvikling tog - eksempelvis de tunesiske og ægyptiske demonstranters succes med at vælte flere efter hinanden følgende overgangsregeringer og de ægyptiske demonstranters succes $\mathrm{i}$ efteråret med at presse militærrådet til løfter om tidlige præsidentvalg.

Den anden type politisering, vi finder relevant, har udspillet sig 'ved siden af' regimerne og de politiske eliter, men inden for rammerne af formaliseret og bureaukratiseret politik. Det drejer som om folkelig deltagelse i valghandlinger. Igennem 2011 har vi set en eksplosiv stigning i folkelig deltagelse i denne form for politik, der i postdemokratiseringslitteraturen, med rette, blev fremstillet som ineffektivt og regimemanipuleret og derfor meningsløs. Første gang, vi så tendensen, var ved den ægyptiske folkeafstemning i foråret om en justeret grundlov, hvor omkring 50 procent af de stemmeberettigede deltog i valghandlingen. Anden gang var efteråret, hvor ca. 50 procent af de stemmeberettigede tunesere (omkring 90 procent af de 'registrerede vælgere') deltog i valget af en grundlovsgivende forsamling. Tredje gang var i november, hvor de første runder af de ægyptiske valg blev gennemført med en valgdeltagelse på omkring 60 procent. Procentsatsen skal ses i forhold til tidligere valghandlinger, der anslås at have mobiliseret mellem ti og 20 procent af de stemmeberettigede og i tilfælde af valg til mindre betydningsfulde politiske institutioner som $\mathrm{fx}$ de ægyptiske kommunalråd eller overhus helt ned til to procent (IFES 2011). Sideløbende med denne revitalisering af vælgerne har vi set en eksplosiv stigning i partidannelser med hundreder af nye partier i Tunesien og Ægypten.

Den tredje type politisering er foregået 'over' regimerne. Den består i en genoplivning af visse af regionens supranationale politiske instrumenter. Vi har således $\mathrm{i}$ 2011 set et aktivt GCC skubbe på regionale politiske løsninger. I foråret så vi GCC ratificere en sanktion vedrørende et flyveforbud i Libyen, før den Arabiske Liga ratificerede en lignende sanktion, der banede vejen for NATO's militære intervention. Og i efteråret har vi set den Arabiske Liga træde yderligere i karakter som en regional politisk spiller, der skal medregnes i Mellemøstens nye politiske landkort med eksklusionen af Syrien i, hvad der fremstår som et forsøg på at håndtere det syriske spørgsmål uden inddragelse af internationale organisationer som $\mathrm{fx}$ FN og NATO.

På hver sin måde udfordrer disse tre typer politisering, 'under', 'ved siden af' og 'over' regimerne (dele af) postdemokratiseringslitteraturens tendens til snævert at fokusere på de politiske strukturer og processer på regimeniveau. Som Sara Ben Nafisa (2011) påpeger, har dele af postdemokratiseringslitteraturens stærke fokusering på bureaukratiseret og formaliseret politik rummet en implicit devalorisering af den politiske betydning af dynamikker og initiativer, der udgik fra den sociale base. Dette forhold betyder ikke, at der ikke igennem de sidste årtier er blevet lavet studier af sociale bevægelser og andre former for contentious politics i Mellemøsten. Tværtimod er der igennem 2000'erne foregået en mærkbar stigning i studiet af fænomenet, som stadfæstedes med Quintan Wiktorowicz's redigerede værk fra 2004. Ligesom værket har det generelle studiefelt omfattet analyser både af bredere ikke-voldelige sociale bevægelser - navnlig af de islamistiske græsrodsbevægelser i regionen (se fx Wickham 2002) - samt af regionens smalle militante bevægelser (se fx Gunning 2009). Mens disse værker generelt har blik for, at de islamistiske bevægelser udgjorde den stærkeste opposition til de autoritære regimer, har de generelt i lighed med mainstream varianten af postdemokratiseringslitteraturen tildelt den sociale base ringe muligheder for at forandre status quo. Studierne af de sociale bevægelser, fra militante til ikke-voldelige, har med andre ord været med til at opretholde forestillingen om regimernes domi- 
nans over den politiske scene - $\mathrm{i}$ visse tilfælde med den konsekvens, at den sociale scene, der typisk fremstilledes som domineret af de islamistiske sociale bevægelser, blev afkoblet fra det politiske felt. Nedvurderingen af den sociale bases mulighed for at generere politisk forandring er naturligvis delvist skabt som følge af postdemokratiseringslitteraturens regimefokus. Samtidig afspejler nedprioriteringen socialvidenskabernes teoretisering af sociale bevægelser, hvis politiske indflydelse beskrives som direkte afhængig af de 'muligheder' (opportunity spaces), der udstikkes fra staten eller regimet i en given kontekst (se fx McAdam, McCarthy \& Zald 1996). I Charles Tillys teori om sociale bevægelser opereres endvidere med en forståelse af, at eksistensen af sociale bevægelser i et givet samfund er ligefrem proportionalt med graden af demokratisk styre: jo mere demokrati, desto flere sociale bevægelser (se fx Tilly \& Wood 2009). Denne stramme korrelationslære inden for social movement-studies synes at have bidraget til en generel nedvurdering af den politiske betydning af de tiltag til at danne sociale bevægelser og kampagner, der rent faktisk kunne observeres inden for de autoritære regimer i Mellemøsten i årene op til 2011. I en ægyptisk sammenhæng kan således nævnes Kefayabevægelsens kampagne imod den planlagte tronfølge fra Hosni Mubarak til Gamal Mubarak i 2004-05, boykotkampagnerne imod israelske og senere danske produkter $\mathrm{i}$ 2003-06, 6. April-bevægelsens kampagne for arbejder- og borgerrettigheder i 2008 og 2009, El-Baradeis kampagne for grundlovsændringer i 2010 og 'Vi er alle Khaled Saids' antipolitivoldskampagne samme år (Svarre \& Boserup 2011; El-Ghobashy 2011). Hertil kommer, at studier af mellemøstlige sociale bevægelser har haft en tendens til at koncentrere sig mere om formelle organisationer, frem for hvad Asef Bayat (2010) har betegnet som nonmovements kendetegnet ved ikke-kollektive aktørers kollektive handling - et fænomen, som, flere har peget på, netop har været et centralt aspekt ved de arabiske revolter (fx Gause 2011, 24).

Den pludselig eksplosion i folkelig deltagelse i valghandlinger fordrer også en nuancering af den fremherskende opfattelse inden for store dele af postdemokratiseringslitteraturen om, at de arabiske samfund var depolitiserede og præget af politisk apati. Udover at der tilsyneladende er foregået mere uden for den formelle politiske scene, end de fleste har været opmærksom på, viser udviklingen i 2011 også, at politisk engagement er nærværende og mobiliserbart i den arabiske verden under forudsætning af, at det opfattes som meningsgivende at deltage i valgene - med andre ord synes folk mere end villige til at stemme, hvis der er en chance for, at deres stemme rent faktisk kommer til at betyde noget.
Sluttelig understreger revitaliseringen af de regionalpolitiske institutioner betydningen af at være opmærksom på, hvordan der også foregår en bredere form for genpolitisering på et regionalt plan, samt hvordan det regionale og nationale spiller sammen. Den generelle tendens inden for postdemokratiseringslitteraturen har været, at det udover regimeniveauet snarere har været globale dynamikker og internationale aktører, at interessen har samlet sig omkring. Selv om der allerede forinden var en voksende opmærksomhed omkring det regionale niveau ( $\mathrm{fx}_{\mathrm{x}} \mathrm{Bank}$ $\&$ Valbjørn 2010), indskrænkede denne sig i reglen til den mellemfolkelige frem for interstatslige dimension heraf. Udover at bekræfte, at det - blandt andet som følge af de nye transarabiske medier (se Skovgaard-Petersen i dette nummer) - fortsat er relevant at betragte den arabiske verden som, hvad Paul Noble i sin tid betegnede som et vast sound chamber, hvor idéer og informationer cirkulerer og har resonans på tværs af landegrænser, er det $\mathrm{i}$ løbet af 2011 også blevet klart, at interstatslige arabiske institutioner, som tidligere har været afskrevet enhver politisk relevans, også fortjener opmærksomhed. I 2011 har vi således set den Arabiske Liga og GCC indtage en historisk ny rolle med beslutninger, som underordnede de interesser, der forfægtedes af regimerne i enkelte nationalstater (Libyen og delvist i Syrien og Yemen) til fordel for regionale interesser.

Ved slutningen af $2011 \mathrm{kan}$ vi således konstatere, at genpolitiseringen af den arabiske verden trods de usikre resultater har påpeget klare behov for en bredere forståelse af, hvad der udgør 'politik' i studiet af mellemøstlig politik. Det er således ikke længere muligt at begrænse sig til et snævert studie af regionens regimer og deres disponeringer. Med den brede politisering af felterne omkring regimerne i 2011 må studiefeltet følge med og indbefatte områderne over, under og ved siden af regimerne - uanset om der på den lange bane overvejende skabes grobund for fortsat autoritarisme eller for nye demokratiske former.

\section{Et opgraderet postdemokratiseringsperspektiv}

Frem for at erklære, at postdemokratiseringsperspektivet har udspillet sin rolle, lægger udviklingen af det empiriske felt i 2011 snarere op til en genovervejelse af perspektivets styrker og svagheder som forskningsprisme. Hvad angår autoritarismestudierne, synes det snævre fokus på regimeniveauet kombineret med en tendens til fokus på kontinuiteten i de tilsyneladende forandringer at have medvirket til, at man overdrev graden af autokratisk stabilitet samtidig med, at man ikke havde tilstrækkeligt blik for, at der faktisk foregik noget uden for den afpolitiserede formelle politiske sfære. På den baggrund overså man i vidt omfang tegnene på de arabiske revolters komme. Udviklingen i regionen gennem 2011 giver på samme tid 
anledning til forsigtighed, når det kommer til demokratioptimismen. Dels bærer en række af de arabiske regimers annoncerede reforminitiativer fællestræk med de seneste to årtiers 'forandre for at bevare'-strategi, og dels er det nyttigt at huske på, at et autokratis sammenbrud ikke behøver at indvarsle demokratiets komme, idet der blot kan komme nye former for autokratier i stedet.

Efter vor mening er der imidlertid meget, der er forandret i regionen og én af de centrale forandringer, som bør tilkendes særlig opmærksomhed, er den politisering, som har kendetegnet arabisk politik gennem det seneste år, og som står i kontrast til de udbredte beskrivelser af de arabiske samfund som afpolitiserede og politisk og socialt apatiske. Denne forandring afspejler sig ikke blot blandt islamister (jf. Utvik i dette temanummer, se også Valbjørn 2011b), men, som vi har beskrevet, blandt alle aktører på den politiske scene, herunder også sekulære, liberale og socialistiske aktører.

Frem for at vende tilbage til 1990'ernes demokrati-optimisme synes det mere nyttigt at tage afsæt $\mathrm{i}$, hvad man - med en parafrasering af Heydemann $(2007)^{2}$ - kunne kalde et opgraderet postdemokratiseringsperspektiv. Altså en tilgang, der søger at tage højde for den berettigede kritik, som denne tilgang har mødt i forbindelse med de arabiske revolter, men som samtidig fastholder postdemokratiseringsperspektivets overordnede ambition om at flytte fokus fra demokrati-optimismens relativt ensidige og normative søgen efter noget ønskeligt, men (måske) fraværende (demokratisk transition), til en interesse for at opnå en bedre forståelse af det faktisk nærværende. En opgradering af perspektivet vil ikke betyde en afvikling af det centrale fokus på regimerne. Der er snarere tale om, at forståelsen af de arabiske autokratiers dynamikker bør suppleres med en bredere politikforståelse, et bedre blik for, hvad der foregår uden for den snævre regimescene og endelig for samspillet mellem sociale dynamikker og politisk forandring. Vi har i nærværende artikel navnlig udpeget tre områder, som vi finder særligt interessante. Det brede felt af contentious politics, der foregår 'under' regimerne. Det revitaliserede felt af folkelig valgdeltagelse, der foregår 'ved siden af' regimerne. Og det snævre, men betydningsfulde felt af regionale aktører, der opererer politisk 'over' regimerne.

\section{Litteratur}

Albrecht, H \& O Schlumberger 2004, 'Waiting for Godot': Regime Change without Democratization in the Middle East', International Political Science Review, vol. 25, no. 4, pp. 371-392.

Amnesty International 2011, Broken Promises, Egypt's Military Rulers Erode Human Rights, Amnesty International, London.
Anderson, L 2006, 'Searching where the Light Shines: Studying Democratization in the Middle East', Annual Review of Political Science, vol. 9, no. 1, pp. 189-214.

Bank, A 2009, 'Die Renaissance des Autoritarismus. Erkenntnisse und Grenzen neuerer Beiträge der Comparative Politics und Nahostforschung', Hamburg Review of Social Sciences, vol. 4, no. 1, pp. 10-41.

Bank, A \& M Valbjørn 2010, 'Bringing the (Arab) regional level back in... - Jordan in the New Arab Cold War', Middle East Critique, vol. 19, no. 3, pp. 303-319.

Bayat, A 2010, Life as Politics: How Ordinary People Change the Middle East, Stanford University Press, Stanford.

Bellin, E 2011, 'Lessons from the Jasmine and Nile Revolutions: Possibilities of Political Transformation in the Middle East?', Middle East Brief - Brandeis University's Crown Center for Middle East Studies, no. 50 .

Boserup, RA 2011, 'Overblik: Efter foråret', Reson10, vol. 2, pp. 43-47.

Boserup, RA \& F Tassinari forthcoming, 'The Return of Arab Politics and Europe's Chance to Engage Anew', Mediterranean Politics, Spring.

Brown, N 2011, 'Post-Revolutionary Al-Azhar', Carnegie Paper, October 2011

Brownlee, J \& J Stacher 2011, 'Change of Leader, Continuity of System: Nascent Liberalization in Post-Mubarak Egypt', Comparative Democratization, vol. 9, no. 2 .

Brumberg, D 2003, Liberalization versus Democracy - Understanding Arab Political Reform', Carnegie Papers - Middle East Series, no. 37.

El-Ghobashy, M 2011, 'Politics by Other Means - In Egypt, Street Protests Set the Agenda', Boston Review, November/December.

Errazzouki, S 2011, 'Moroccos next government new actors same script', Jadaliyya Blog, December 22.

Fukuyama, F 1989, 'The End of History?', The National Interest, vol. 16, Summer, pp. 3-18.

Fukuyama, F 2011, 'Political Order in Egypt', The American Interest, vol. 6 , no. 5 , pp. 7-12.

Gause, G 2011, 'The Middle East Academic Community and the 'Winter of Arab Discontent", i Laipson (red.), Seismic Shift-Understanding Change in the Middle East, The Henry L. Stimson Center, Washington D.C.

Gershman, C 2011, 'The Fourth Wave', The New Republic, March 14.

Goldberg, E 2011, 'Mubarakism Without Mubarak - Why Egypt's Military Will Not Embrace Democracy', Foreign Affairs Snapshot, February 11.

Gunning, J 2009, 'Social Movement Theory and the Study of Terrorism', i R Jackson, MB Smyth \& M Gunn (red.), Critical Terrorism Studies: Framing a New Research Agenda, Routledge, New York.

Halliday, F 2002, 'A New Global Configuration', i K Booth \& T Dunne (red.), Worlds in Collision - Terror and the Future of Global Order, Palgrave, New York.

Heydemann, S 2002, 'La question de la démocratie dans les travaux sur le monde arabe', Critique International, no. 17 (October), pp. 54-62.

Heydemann, S 2007, 'Upgrading Authoritarianism in the Arab World', Brookings Inst. - Saban Center Analysis Paper, October, Brookings, Washington.

Heydemann, S \& R Leenders 2011, 'Authoritarian Learning and Authoritarian Resilience: Regime Responses to the 'Arab Awakening", Globalizations, vol. 8, no. 5, pp. 647-653.

Hudson, M 1991, 'After the Gulf War: Prospects for Democratization in the Arab World', Middle East Journal, vol. 45, no. 3, pp. 409-426.

Hudson, M 2011, 'Awakening, Cataclysm, or just a Series of Events? Reflections on the Current Wave of Protest in the Arab World', Jadaliyya Blog, May 16. 
Human Rights Watch 2011, Targets of Retribution, Attacks against Medics, Injured Protestors, Health Facilities, Human Rights Watch, July 18, 2011.

Huntington, SP 1968, Political Order in Changing Societies, Yale University Press, New Haven.

IFES 2011, 'Elections in Egypt, Key Challenges for Credible and Competitive Elections', IFES Briefing Paper, February 5, 2011.

Kienle, E 2001, A Grand Delusion: Democracy and Economic Reform in Egypt, I.B. Tauris, London.

Lobe, A 2011, 'Politologie: Die Wissenschaft vom stabilen Orient', Frankfurter Allgemeine Zeitung, 24. März.

Lynch, M 2011, 'After Egypt: The Limits and Promise of Online Challenges to the Authoritarian Arab State', Perspectives on Politics, vol. 9, no. 2, pp. 301-310.

McAdam, D, J McCarthy \& M Zald 1996, Comparative Perspectives of Social Movements: Political Opportunities, Mobilizing Structures and Cultural Frames, Cambridge University Press, Cambridge.

Nafisa, SB 2011, 'Révolution civile et politique en Egypte', Mouvements, no. 66, pp. 56-61.

Norton, AR 1993, 'The Future of Civil Society in the Middle East', Middle East Journal, vol. 47, no. 2, pp. 205-216.

Ottaway, M 2011, 'Egypt's Democracy, Between Military, Islamists, and Iliberal Democrats', Carnegie Commentary, November 3, 2011.

Ottaway, M \& M Muasher 2011, 'Arab Monarchies - change for reform, yet unmet', Carnegie Papers - Middle East, December 2011.

Schlumberger, O 2007, Debating Arab Authoritarianism Dynamics and Durability in Nondemocratic Regimes, Stanford University Press, Stanford.

Schlumberger, O 2011, 'Nahost-Experten, echte und andere', Frankfurter Allgemeine Zeitung, March 31.

Svarre, BL \& RA Boserup 2011, Actors in a Changing Egypt. 31-siders landeanalyse rekvireret af det danske udenrigsministerium, 4. marts, 2011. En kopi kan konsulteres på biblioteket i Dansk Institut for Internationale Studier.

Tassinari, F \& RA Boserup 2011, 'Tunisia: Wasn't this what we hoped for?', Open Democracy, 14 October.

Tilly, C \& LJ Wood 2009, Social Movements, 1768-2008, Paradigm Publishers, Colorado.
UNHRC 2011, Report of the Independent International Commission of Inquiry on the Syrian Arab Republic, UNHRC, 23 November 2011.

Valbjørn, M 2010, 'Post-democratization lessons from the Jordanian 'success story", Foreign Policy - The Middle East Channel, June 16.

Valbjørn, M 2011a, 'Vil Kong Abdallah reformere Jordan?', i LE Andersen, H Hajjaj \& CB Kjersgaard (red.), Arabisk forår: baggrund og konsekvenser, Ræson, København.

Valbjørn, M 2011b, 'Vil det nye Mellemøsten blive (post)islamistisk?', Militert Tidsskrift, vol. 140, no. 3, pp. 211-222.

Valbjørn, M 2012, 'Upgrading post-democratization studies: Examining a re-politicized Arab world in a transition to somewhere', Middle East Critique, vol. 21, no. 1.

Valbjørn, M \& A Bank 2010, 'Examining the 'post' in Post-democratization - The future of Middle Eastern political rule through lenses of the past', Middle East Critique, vol. 19, no. 3, pp. 183-200.

Wickham, CR 2002, Mobilizing Islam - Religion, Activism, and Political Change in Egypt, Columbia University Press, New York.

Wiktorowicz, Q (ed.) 2004, Islamic Activism: A Social Movement Theory Approach, Indiana University Press, Bloomington.

\section{Noter}

1 For en længere og mere nuanceret fremstilling af denne udvikling med udførlige referencer til centrale værker inden for disse to traditioner, se Valbjørn \& Bank (2010).

2 Heydemann talte i 2007 således om, hvordan de arabiske autokratier var blevet 'opgraderet' af globaliseringen. 